Драган У. Калаба, Заменик вишег јавног тужиоца у Чачку

\title{
ИЗУЗЕһЕ СУДИЈЕ
}

САЖЕТАК: У овом раду, акценай је дай на разлог̄ изузећа иредвиђен у чл. 40. сй. 1. й. 4. ЗКП „да је судија у истиом кри-

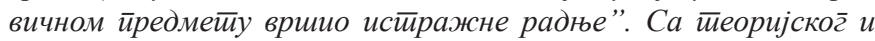
иракииччног сииановишйа важно је, када се осивваре услови за изузеће судије, иредвиђено у ЗКП, да се истии искључи из даљеге

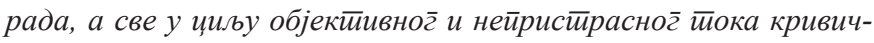

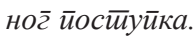

Кључне речи: кривични йосйуйак, изузеће судија, наредба, истиражна радња

\section{УВОД}

„Странке и остали учесници кривичног поступка предузимају радње регулисане Законом о кривичном поступку, а свим тим радњама руководи председник већа - судија, као лице изабрано по одређеној процедури предвиђеној у Закону о судијама, лице које је положило заклетву, судија је дужан да у поступку поступа неутрално и непристрасно." изузеће као установа кривичног процесног права представља пут и начин помоћу кога се из поступка одстрањује судија када постоје одређени разлози који га чине неподобним за вршење судијске функције или побуђују сумњу у његову непристрасност.

* Рад примљен: 26. 12. 2011. године.

1 „Изузеће судије на основу чл. 39. ст. 1. т. 6. ЗКП” - Драган У. Калаба, судија Општинског суда у Гучи, Билтен Окружног суда у Београду број 3/90, стр. 123. 
Између осталог, а по чл. 40. ст. 1. т. 4. ЗКП (Службени глласник РС бр. 20. и 79. из 2009) предвиђено је да судија не може вршити судијску ДУЖНОст - АКО ЈЕ У ИСТОМ ПРЕДМЕТУ ВРШИО ИСТРАЖНЕ РАДЬЕ.

У овом раду ће се посебно анализирати појмови „наредба” и „истражна радња" и који услови треба да се остваре да би конкретни судија био изузет из даљег рада у текућем предмету.

\section{ИЗУЗЕһЕ СУДИЈЕ У КОНКРЕТНОМ ПРЕДМЕТУ Повод рада - случај из судске праксе}

Пред Вишим судом у Чачку окончан је главни претрес у предмету К 1/11 дана 7. новембра 2011. доношењем неправноснажне пресуде којом су окривљени оглашени кривим због више кривичних дела. Исто судеће веће је истог дана донело решење којим је окривљенима продужен притвор сходно чл. 142. ст. 1. т. 6. ЗКП. Апелациони суд у Крагујевцу је својим решењем Кж 2158/11 од 28. новембра 2011, уважавањем жалбе бранилаца окривљених и по службеној дужности укинуо решење Вишег суда у Чачку и предмет вратио првостепеном суду на поновно одлучивање. У образложењу другостепеног решења, између осталог, је наведено: „основано се истиче у жалби бранилаца, да је побијано решење захваћено битном повредом одредаба кривичног поступка из чл. 368. ст. 1. т. 2. ЗКП-а јер је на главном претресу суделовао судија који се по одредбама чл. 40. ст. 1. т. 1. до 5. ЗКП-а морао изузети. Наиме, из списа произилази да је председник већа првостепеног суда судија М. Р., као истражни судија у датом поступку, предузела радње издавања наредби којом се наређује надзор и снимање телефонских и других разговора или комуникација другим техничким средствима и оптичка снимања за лица којима се суди у датом поступку и то две наредбе са бројевима... у вези са тим, Апелациони суд налази да је издавање овакве образложене наредбе у вези са надзором и снимањем телефонских разговора, радња која је од утицаја на даљи ток кривичног поступка и као таква представља истражну радњу због чега председник већа - судија М. Р. није могла да учествује у доношењу одлуке о притвору, сходно чл. 40. ст. 1. т. 4. ЗКП, услед чега је било нужно укинути побијано решење и предмет вратити првостепеном суду на поновно одлучивање."

Дакле, закључак другостепеног суда је да председник већа - судија није могла да донесе решење о продужењу притвора јер је у фази истраге а у истом предмету донела две наведене образложене наредбе. То даље значи да треба, а у циљу правилног решења ове процесне ситуације, изврши- 
ти анализу појма „наредбе”, појма „истражне радње”, појма „вршења”, па закључити може ли наведени судија да буде изузет из даљег тока поступка.

Нужно је поново указати да је цитирано решење другостепеног суда повод за писање овог рада, повод за размишљање и давање аргумената у правцу одговора, а што значи да могу да се изнесу супротна схватања.

\section{ИСТОРИЈАТ УСТАНОВЕ ИЗУЗЕһА - чЛ. 40. ст. 1. Т. 4. ЗКП-а}

У Законику о поступку судском у кривичним делима из 1865 . године, у глави V, § 43 је наведено да „не може ислеђивати казнено дело онај...” Односно на поменутом месту се говори о искључењу судије из даљег ислеђивања, али не постоји одредба која би указивала на изузеће судије ако је вршио истражне радње односно „иследне радње”.

У Законику о судско-кривичном поступку за Краљевину Југославију из 1929. године постоји у глави III наслов „Искључење и изузеће”, па у § 28. и 29. су наведени основи искључења, те је наведено да „не може судити ни онај који је у истом предмету вршио извиђајне или истражне радње у поступку пре главног претреса".

Поводом овог Законика, аутор др Б. Марковић наводи: „Само за суделовање и решавање на главном претресу, искључен је онај судија који је у истој кривичној ствари вршио извиђајне или истражне радње пре главног претреса. У поступку пред Среским судом неће бити искључен да врши главни претрес судија који је извршио извиђаје (§ 385), јер је овде поступак брз и кратак и извиђаји се врше само утолико уколико је потребно да се може наредити усмени главни претрес (§ 377). Неће бити искључен замољени судија, тј. судија Среског суда који није водио ни извиђај ни истрагу већ је само на молбу истражног судије, место овога обавио извесне процесне радње..."2

Коментаришући исте параграфе, аутор др М. Чубински наводи: „Према $\S 29$. као основ за искључење пре свега се јавља вршење у истом предмету извиђајних или истражних радњи. Горње правило је изражено у потпуно категоричкој форми и стога не би допуштало ма које изузетке, али тих изузетака има и исти су изречно наглашени у другим параграфима нашег Законика о кривичном поступку. Тако код Среског суда, судија који је вршио извиђај није искључен да врши усмени претрес."з

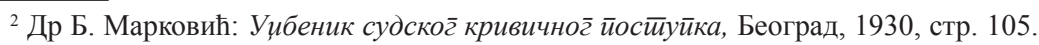

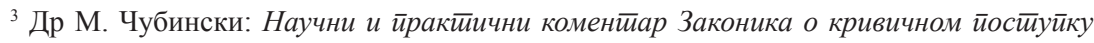
Краљевине Југоославије, Београд, 1933, стр. 119. 
Дакле, акценат цитираних решења/параграфа је да је изузет судија који је пре главног претреса вршио истражне радње, а то преведено на терен садашњег Законика о кривичном поступку, да је изузет судија који је у фази истраге вршио односно извршио истражне радње, односно радње доказивања, а што је све учињено пре главног претреса.

Сходно цитираним коментарима и садашњи ЗКП у чл. 444. ст. 2. предвиђа да судија који је спроводио истражне радње није изузет да поступа на главном претресу, а ова суштина се односи на тзв. скраћени поступак.

Понављајући цитирани део др Б. Марковића, који се односи на то да није изузет замољени судија који обавља неку процесну радњу, исти можемо превести на данашњу могућу ситуацију у судовима, а што се огледа у следећем. На пример, одређени истражни судија води истрагу у конкретном предмету, па изненада не дође на посао било услед личне спречености, службене одсутности и друго. Тада други судија, обично у кривичној материји, донесе наредбу за вештачење (било које) или пак донесе две наредбе (као из цитираног решења Апелационог суда). То даље значи да судија који је донео само наредбу о вршењу одређене истражне радње које ће извршити не он већ надлежна установа - Безбедносно информативна агенција, МУП или други органи. Да ли сада судија (други судија) који није вршио ни извршио истражну радњу (нпр. прислушкивања, снимања и др.) може бити изузет из сопственог рада на главном претресу?

У донетим Зконима односно Законицима о кривичном поступку у периоду од 1945. до 2011. године у суштини је иста одредба да се судија мора изузети ако је у истом предмету вршио истражне радње.

\section{УСЛОВИ ПРИМЕНЕ ИНСТИТУТА ИЗУЗЕТА}

Да би се применио институт изузећа у конкретном случају, а што произилази из садржине цитираног решења Апелационог суда у Крагујевцу, мора се одговорити на више питања. Шта је и који је значај донете наредбе истражног судије, ко је ту наредбу реализовао/извршио и да ли се може сматрати да је истражни судија вршио истражне радње већ самим доношењем наредбе, па и ако није образложена.

У чл. 154. ст. 1. ЗКП је наведено да у кривичном поступку одлуке се доносе у облику пресуде, решења и наредбе. За разлику од пресуде и решења, Законик о кривичном поступку не одређује које елементе, односно састав наредба мора да садржи. Како је у конкретном случају реч о истражном судији, у многим одредбама Законика о кривичном поступку се наводи да се доноси наредба, а у некима да се доноси образложена 
наредба. Нигде у Законику о кривичном поступку није наведено какав је значај једне наредбе у односу на другу, која је њихова међусобна јачина и да ли се међусобно разликују у односу на њихову садржину или према чињеници ко коју наредбу спроводи. Може се рећи да је наредба свака одлука која није ни пресуда ни решење, а које су у ствари директиве којима се управља ток кривичног поступка.

Општа заједничка карактеристика свих наредби је у томе што против наредбе нема никаквог правног лека. То даље значи да сваки орган - учесник кривичног поступка није овлашћен да донесе сваку наредбу. У Законику о кривичном поступку је тачно одређено које наредбе нпр. може да донесе само истражни судија.

Законик о кривичном поступку није предвидео обавезну форму наредбе, али се у пракси усталила одређена форма која произилази из суштине наредбе и њене улоге у кривичном поступку. Наредба треба да садржи уводни део - ко је доноси, на кога се односи у вези са одређеним кривичним делом, законски основ доношења, датум доношења, затим садржину наредбе - на шта се односи, када и ко је има извршити. Исту потписује лице које је издало наредбу и ставља се службени печат. У пракси се показало да наредба која нема образложење (формално издвојено) у ствари има своје образложење које је обухваћено диспозитивом, из којег се виде разлози за доношење исте.

Конкретне, спорне наредбе истражног судије су образложене и донете на основу одредбе чл. 504. ЗКП-а.

А сада о истражним радњама.

„Истражне радње представљају одређени, законом регулисани начин откривања и утврђивања извесних података о кривичном делу и учиниоцу. Посматрајући истражне радње у односу на чињенице и доказе, неке од њих представљају извођење доказа (саслушање сведока, вештачење), неке имају значај за откривање доказа (увићај, претресање стана и лица), односно њихово обезбеђење (привремено одузимање предмета), као и њихово проверавање (реконструкција). Заједнички назив „истражне радње” оне су добиле само због тога што се најчешће обављају у истрази, али је неке од њих могуће извршити и пре покретања кривичног поступка као и у његовим каснијим фазама."

„Под појмом вршења истражне радње не подразумева се обављање појединих процесних радњи у фази главног претреса. Веће на главном претресу може под одређеним условима овластити председника већа или судију члана већа, да ван главног претреса саслуша сведоке или вештаке или да изврши увиђај али се те радње не сматрају истражним радњама.

${ }^{4}$ Др Загорка Симић-Јекић, Кривично ирроиесно йраво, Београд, 1982, стр. 213-214. 
Истражним радњама у смислу цитираног прописа сматрају се само оне радње које су предузете у претходном кривичном поступку."

Ако се повежу претходно поменута схватања са изложеном садржином коментара ЗКП Краљевине Југославије јасно је да се, прво, истражна радња обавља у фази истраге односно „пре главног претреса”, друго, оно се односи на извођење односно вршење истражне радње а која је садржана у наредби и, треће, њена суштина је у вршењу - извођењу - реализацији садржине наредбе.

Зато, са потпуним правом, аутор Лука Бренеселовић истиче да „када је реч о доказним радњама, потребно је да их је судија вршио, а не само да их је наредио или одобрио"6.

Такође, аутор мр Светислав Вуковић правилно закључује да „под вршењем истражних радњи не подразумева се нека сасвим споредна радња као што је позивање сведока, вршење саопштења, учешће у седници већа, решавање о приговору против оптужнице, одлучивање о спровођењу и слично"'

Ако повежемо поменуте коментаре са нпр. установом „спровођења” односно довођења окривљеног сходно чл. 135. ЗКП, уочава се да се доноси наредба о довођењу окривљеног у суд. Дакле, то је само процесна радња од стране истражног судије, а реализацију исте спроводи не судија већ надлежни орган - Министарство унутрашњих послова.

Интересантно је да аутор др Момчило Грубач, о овој процесној ситуацији закључује на следећи начин: „Сматрамо да би најбоље решење било да се на тим пословима не ангажује судија који је раније обављао истражне радње, што се лако да спровести. На тај начин би се избегла сувишна дискусија."8

Упадљиво је да, у овом делу, познати аутор и писац Коментара Законика о кривичном поступку не даје одговор на питање шта је вршење истражне радње и који се судија изузима, иако текући "живот" у правосуђу, а који аутор не примећује, управо ствара овакве ситуације. Дакле, после достављања оптужнице суду заједно са списима „Ки”, водилац кривичног уписника, а кога не интересује шта је истражна радња и ко ју је вршио, заводи предмет у уписник „К” и додељује га судији по редоследу, па тек тада судија који је предметом задужен, уочава да је у том истом предмету

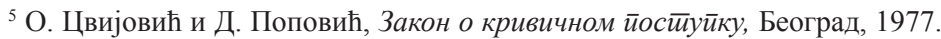

${ }^{6}$ Лука Бренеселовић, Изузеће судије у кривичном йостиуйку, Анали Правног факултета у Београду бр. 1/2007.

${ }^{7}$ Мр Светислав Вуковић, Коменйар Закона о кривичном йосйуйку са судском йраксом, Београд, 2002, стр. 47.

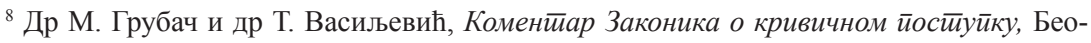
град, 2010, стр. 103. 
донео наредбу као истражни судија, мењајући истражног судију који је водио основни истражни предмет, и тек у том моменту се отвара питање да ли судија треба да се ослободи даљег вођења поступка.

У закључку, истичем да доношење наредбе, па и образложене наредбе „као што су и спорне у конкретном случају” од стране истражног судије, а коју је спровео други орган, а у конкретном случају је то извршила Безбедносно информативна агенција не ослобађа тог судију од вођења тог предмета на главном претресу, односно није изузет јер није вршио истражне радње у конкретном предмету.

\section{СУДСКА ПРАКСА}

У прилогу изложеног става, износим објављене судске одлуке које третирају ову материју а које су основ овог стручног рада.

- „Истражни судија који је спроводио истражне радње, не може бити члан ванрасправног већа које доноси одлуку о приговору на оптужницу по истом предмету" (ВСС - Кз3 14/96). ${ }^{9}$

- „Учествовање у претходном поступку у већу, не може се сматрати као вршење извиђајних и истражних радњи због чега се, по наведеном законском пропису не може прихватити тражење изузећа таквог судије од учествовања у пресуђењу на главном претресу” (ВСС-Кж 780/67). ${ }^{10}$

- „Не представља основ за изузеће суца од вршења судачких дужности по чл. 38. т. 4. ЗКП околност, да је улазио у канцеларију, у којој је други истражни судац у истом кривичном предмету вршио истражне радње, јер само такво његово присуствовање нема значења вршења истражне радње" (Врховни суд Хрватске Кж 3233/57)."11

- „Судија не може вршити судијску дужност председника већа на главном претресу уколико је у истом кривичном предмету вршио истражне радње, али се вршењем истражне радње не може сматрати издавање наредбе судије органу унутрашњих послова да изврши претрес стана" - у образложењу је наведено да „председник већа који је учествовао у првостепеном поступку и доношењу пресуде није у преткривичном поступку вршио истражне радње - претрес стана, већ су ову истражну радњу изстр. 49.

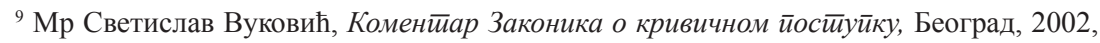

${ }^{10}$ Истио.

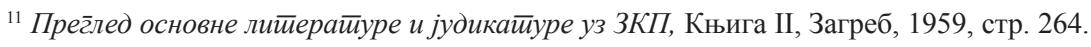


вршили органи унутрашњих послова сходно чл. 189. ст. 3. ЗКП” (пресуда Окружног суда у Нишу Кж 1736/06 од 28. маја 2007). ${ }^{12}$

- „Судија који је вршио истражне радње не може поступати у истом кривичном предмету у поступку за пуштање на условни отпуст" (пресуда Врховног касационог суда Кзз 203/10 од 26. јануара 2011). ${ }^{13}$

- „Судија који је вршио истражне радње не може вршити судијску дужност у истом предмету као члан ванрасправног већа" (пресуда Врховног касационог суда Кз3 7/10 од 3. марта 2010). ${ }^{14}$

- „Суделовање судије који је у истом кривичном предмету вршио истражне радње, у већу које после подизања оптужнице одлучује о притвору, представља битну повреду одредаба кривичног поступка из чл. 364. ст. 2. ЗКП која је учињена у време припремања главног претреса, јер суд није применио одредбу чл. 39. ст. 1. т. 4. ЗКП, те је то могло бити од утицаја на правилно и законито доношење одлуке" - у образложењу одлуке је наведено да је ,у истом кривичном предмету вршио истражне радње, односно у истрази је саслушао окривљеног, те у смислу чл. 39. т. 4. ЗКП морао бити изузет” (пресуда Врховног суда Србије Кж 2/95 - Билтен судске праксе Врховног суда Србије број 1/1995). ${ }^{15}$

- „Издавање наредбе о обдукцији леша не сматра се вршењем истражне радње, па истражни судија који је наложио предузимање обдукције није изузет од учествовања на главном претресу у истој ствари" - у образложењу одлуке је наведено да „само издавање наредбе о извршавању обдукције над лешом од стране вештака не сматра се учествовањем у истрази, а из обдукционог налаза произилази да је обдукцију извршио вештак у стручној установи, па присуство истражног судије није било обавезно, нити је истражни судија истој присуствовао" (пресуда Врховног суда Србије Кж 1014/05 од 7. септембра 2005). ${ }^{16}$

- „Учешће судије - председника већа у раду ванрасправног већа не представља битну повреду одредаба кривичног поступка због које би он морао бити изузет од поступања у смислу чл. 40. ЗКП” (пресуда Окружног суда у Ваљеву Кж 572/07 од 6. децембра 2007. - Билтен Окружног суда у Ваљеву број 2/2008). ${ }^{17}$

\footnotetext{
${ }^{12}$ Параг̄раф - правна база.

${ }^{13}$ Исйо.

${ }^{14}$ Истио

${ }^{15}$ Исйо.

${ }^{16}$ Истио

${ }^{17}$ Иниеермекс - правна база.
} 
- „Чињеница да је окривљени поднео приватну кривичну тужбу против судије који суди у његовој кривичној ствари због кривичног дела из чл. 359. КЗ односно да је поднео кривичну пријаву или предузео гоњење оптужницом оштећеног као тужиоца која није ступила на правну снагу, није разлог за изузеће судије у смислу чл. 40. ЗКП” (Решење Вишег суда у Краљеву Су 39/10 од 26. фебруара 2010. - Билтен Вишег суда у Краљеву бpoj 1/1020). ${ }^{18}$

- „Судија у смислу чл. 40. т. 4. ЗКП не може вршити судијску дужност председника већа на главном претресу уколико је у истом кривичном предмету вршио истражне радње, али се вршењем истражне радње не може сматрати издавање наредбе органу унутрашњих послова да изврши претрес стана" (Пресуда Окружног суда у Нишу Кж 1736/06 - Билтен судске праксе Окружног суда у Нишу број 25/07). ${ }^{19}$

- „Када је на главном претресу учествовао као председник већа судија који је у својству дежурног истражног судије обавештен од МУП-а о догађају који је судио и истом издао налоге за поступање, то није разлог за његово изузеће" (пресуда Врховног суда Србије Кж 537/06 од 1. јуна 2006. - Билтен Окружног суда у Београду број 75/07). ${ }^{20}$

- „Нису испуњени услови за изузеће судије када је била присутна приликом испитивања окривљеног од стране истражитеља Хашког трибунала као једна од судија Већа за ратне злочине, сходно Закону о сарадњи са Хашким трибуналом" (Пресуда Врховног суда Србије - Већа за ратне злочине Кж 3/06 од 26. фебруара 2007. - Билтен Вишег суда у Београду број 81/11). ${ }^{21}$

- „Одлучивање о захтеву за заштиту законитости Републичког јавног тужиоца у кривичном предмету због кривичних дела тешко дело против безбедности саобраћаја" - у образложењу одлуке је наведено да „имајући у виду да је у овом кривичном предмету истражне радње спровео истражни судија... а да је затим био члан Већа Апелационог суда у Новом Саду које је донело решење Кж..., то је поменутим решењем повређена одредба чл. 40. т. 4. ЗКП у корист окривљеног јер се судија... није изузео од поступања у истом кривичном предмету, а што је био дужан да учини. Налазећи да је захтев за заштиту законитости јавног тужиоца основан, Врховни касациони суд је утврдио да је решењем Апелационог суда у Новом Саду повређен закон у корист окривљеног, не дирајући у правноснажно решење
${ }^{18}$ Истйо.
${ }^{19}$ Истио
${ }^{20}$ Истио .
${ }^{21}$ Истио . 
против кога је захтев подигнут” (пресуда Врховног касационог суда Кзз 203/10 од 26. јануара 2011). ${ }^{22}$

- „Ако је председник већа - судија учествовао у споредној истражној радњи, нема разлога за изузеће применом чл. 40. т. 4. ЗКП” - у образложењу одлуке је наведено „чињеница је да је председник већа пред којим је одржан главни претрес као дежурни истражни судија обавештен о саобраћајној незгоди, али исти није предузео ниједну истражну радњу, то није постојала законска сметња да поступа у првостепеном поступку" (пресуда Окружног суда у Чачку Кж 297/09 од 8. јула 2009). ${ }^{23}$

- „Постојаће основ за изузеће судије као члана ванрасправног већа које одлучује о приговору на оптужницу, ако је тај судија у истом предмету спроводио истражне радње” (пресуда Врховног суда Србије Кз3 14/96 од 10. маја 1996). ${ }^{24}$

- „Када је председник већа - судија учествовао у истражним радњама у истом предмету јер је саслушао окривљене као осумњичена лица у својству дежурног истражног судије, морао се изузети сходно чл. 40. т. 4. ЗКП као председник већа од поступања у кривичном предмету, па како то није учинио, доношењем пресуде учињена је битна повреда одредаба кривичног поступка из чл. 368. ст. 1. т. 2. ЗКП” (пресуда Врховног суда Србије Кзз 90/04 од 23. марта 2005). ${ }^{25}$

- „Судија који је у истој ствари као члан ванрасправног већа учествовао у одлучивању о продужењу притвора против окривљеног, може учествовати на главном претресу, па не постоји битна повреда одредаба кривичног поступка из чл. 368. ст. 1. т. 2. ЗКП”- - образложењу одлуке је наведено „само учешће наведених судија у својству чланова ванрасправног већа из чл. 24. ЗКП не може представљати разлог за њихово изузеће по чл. 40. ЗКП” (пресуда Врховног суда Србије Кж 1637/05 од 27. октобра 2005). ${ }^{26}$

- „Неће постојати разлог за изузеће судије из чл. 39. т. 4. ЗКП, ако је он учествовао у истом кривичном предмету у ванрасправном већу које je у фази истраге одлучивало о одређивању притвора против окривљеног пошто се то не може сматрати вршењем истражних радњи” (решење Врховног суда Србије Кж 525/96 од 9. јула 1996). ${ }^{27}$

\footnotetext{
${ }^{22}$ Иниеермекс - правна база.

${ }^{23}$ Профи-систием, Смедерево - правна база.

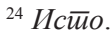

${ }^{25}$ Исйо .

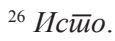

${ }^{27}$ Профи-систием, Смедерево - правна база.
} 